\title{
Academic Dishonesty and E-Learning Dilemma: Conceptual Insight and Implication for Accounting Educators
}

\author{
Andri Zainal ${ }^{1 *}$, Rini Herliani ${ }^{1}$, Ulfa Nurhayani ${ }^{1}$, Khairunnisa Harahap ${ }^{1}$ \\ ${ }^{1}$ Faculty of Economics, Universitas Negeri Medan, Medan, Indonesia \\ *Corresponding Author. Email: andrizainal@unimed.ac.id
}

\begin{abstract}
Technological developments have changed the face of learning at various levels of education with the evolution of E-learning-based learning. Specifically, during the Corona Virus Disease-19 (COVID-19) pandemic, the dimensions of distance and time are no longer a problem. Still, E-learning cannot necessarily replace the function of social interaction, especially for moral education. This presents a dilemma in ensuring that practical moral activities occur during E-learning lectures, which affects their preferences to continue adapting and adopting various E-learning platforms in carrying out their pedagogical and professional tasks. The development of the Elearning dilemma research model for Accounting lecturers is also based on relevant empirical studies. It shows that lecturers' understanding of the seriousness of Academic Dishonesty (AD) problems and the imposition of sanctions for $\mathrm{AD}$ actions has a direct and indirect effect on the dilemma of adopting E-learning and preferences for sustainable use of E-learning.
\end{abstract}

Keywords: Academic Dishonesty (AD), E-Learning Dilemma, E-Learning Preference, Sanctions on $A D$, the Unity Theory of Acceptance and Use of Technology (UTAUT).

\section{INTRODUCTION}

In the era of the Industrial Revolution 4.0 and welcoming the era of Society 5.0, IT and its various applications are considered the primary means to support the learning process and are increasingly being used in various higher education institutions around the world [1], [2]. E-learning is defined as "the use of computer network technology, especially through the Internet, to provide information and instructions to individuals" [3]. The more advanced developments in IT also have an impact on the education sector through the adoption of E-learning-based learning, especially in Synchronous, Asynchronous, and Blended are mandatory choices for the academic community in aligning learning mechanisms according to the dynamics of the times [5], [6], [7], [8], [9].

The role of attitude in explaining technology acceptance has been studied in previous literature (see: [10], [11]). The effect of the attitude variable in the IT acceptance model is consistent with TRA [12] and TPB [13]. The relationship between attitudes and behavioral intentions represented in TAM implies that the positive attitudes of IT users influence a person's intention to use IT. In this conceptual review, attitudes are reflected in the E-learning dilemma variable, which shows the beliefs and perspectives of the users towards the IT tools and infrastructure used in the Elearning process.

The proxy for the attitude in question was developed from the instrument used in the research [14], which includes two main dimensions of the Unity Theory of Acceptance and Use of Technology (UTAUT). namely: expected performance (performance expectancy) and outstanding effort (effort expectancy). The lecturer's dilemma in using Elearning shows the lecturer's negative perception of the use of E-learning. Especially in this situation affected by COVID-19, lecturers tend to compromise and lose in virtual learning. Therefore, they also do not have high expectations for learning performance and their efforts in optimizing the learning outcomes in question [15]. The compromising nature in question is illustrated through their perception of the complexity 
of $\mathrm{AD}$ problems and the imposition of sanctions for $\mathrm{AD}$ actions in conditions of full use of E-learning adoption in the learning process. The criticism on the full adoption of E-learning which relatively prioritizes speed rules (for example, in delivering materials and assignments) rather than prioritizing learning substance (flash over substance), has an impact on neglecting the supposed learning content [15]. Thus, the expected outcomes of E-learning practice are not comparable to the efforts expended by both lecturers as operators and students as users. E-learning is like fulfilling the need for formality and administrative completeness of lectures. It creates a dilemma for lecturers in actualizing their professional and pedagogical competencies. The compromising behavior of $\mathrm{AD}$ in E-learning practice, especially in situations affected by COVID 19, ultimately limits the role of lecturers as agents for changing students' moral character. Lecturers, directly and indirectly, provide space for students to take AD actions in various forms. This permissive attitude also makes lecturers limit themselves to imposing strict sanctions on students even though lecturers realize that the actions taken can have a negative impact on the character of prospective alumni who will take part in various public activities in the future [15], [16], [17].

\section{THE IMPLICATION OF UTAUT ON E- LEARNING}

Individuals' adoption and use of IT is the spirit of research related to information systems. Several theoretical foundations emphasize the primary dependent variable: behavioral intention to use a system [18], [4]. Behavioral intention is defined as "a person's subjective probability that he will perform a certain behavior" [19]. In 2003, Venkatesh et al. proposed the Unity Theory of Acceptance and Use of Technology (UTAUT) based on a consolidation of eight models and theories that interconnected, namely, Theory of Reasoned Action (TRA), Theory of Planned Behavior (TPB), Technology Acceptance Model (TAM), Motivation Model (MM), Model of Personal Computer Use (MPCU), Innovation Diffusion Theory (IDT), Social Cognitive Theory (SCT), and the Integration of Technology Acceptance Models and Planned Behavior [18], [1].

Specifically, in UTAUT, [18] synthesized that IT user attitudes affect behavioral intention to use IT. As an extension of TRA and TPB, UTAUT also concludes that individual behavior is influenced by their attitude towards the outcome of their behavior and the opinions of other individuals in their social environment. According to Ajzen and Fishbein, TRA is a psychological process model that mediates the observed relationship between behavior and attitudes [13]. TPB, which is based on TRA, is built on the assumption that humans generally act rationally by considering all available information and paying attention to the consequences of their behavior. Ajzen proposed the TPB in 1985 as an extension of the TRA, which also attempted to address its shortcomings [12], [13].

According to TPB, an individual's intention to perform or avoid a particular behavior is the most critical determinant of whether that behavior is exhibited [12]. The dilemma of full E-learning adoption faced by lecturers in a condition where AD handling policies, both from the point of view of lecturers and institutions, are relatively loose also impacts preferences for sustainable use of E-learning. The seriousness of $\mathrm{AD}$ and the policies taken regarding $\mathrm{AD}$ in practice also reflect social conditions that influence individual attitudes in doing or avoiding certain behaviors. The behavior in question is the sustainable use of E-learning in the future. Although in the special conditions of COVID-19 where the policy of using E-learning is mandatory for lecturers and students and the potential for adopting it in the future is also relatively large - it does not necessarily make lecturers voluntarily take full advantage of the E-learning platform in actualizing their professional dan pedagogy related-competencies. In line with the essence of TPB, the potential degradation factor for the formation of moral character in the neglect of ideal learning content as a result of the full implementation of E-learning becomes the basis for lecturers' considerations in carrying out or avoiding the behavior of using E-learning sustainably in the future [15], [12], [13].

\section{PROPOSED RESEARCH MODEL}

In general, the research model of the relationship between Academic Dishonesty, E-Learning Dilemma, and Its Impact on the Sustainability of E-Learning Utilization for Accounting Lecturers was developed from the Unified Theory of Acceptance and Use of Technology (UTAUT) by [4]. In this study, the construct of acceptance of IT is proxied in the Elearning Dilemma variable against the E-learning use preference variable, which reflects the behavioral intention construct to use IT (behavioral intention) in the UTAUT model [4]. In addition, the social cognitive essence that characterizes UTAUT is reflected in the context of $\mathrm{AD}$, which consists of sanctions given for $\mathrm{AD}$ actions and the seriousness 
variable of $\mathrm{AD}$ problems as endogenous variables in this research model. This proposed study aims to confirm [15] criticism of the full use of E-learning. It highlights the factor of leniency in applying academic ethics in the use of E-learning so that it impacts the benefits obtained by lecturers as operators. In addition, the professional and pedagogical conflicts experienced by Accounting lecturers over the implementation of Elearning, mainly because it was affected by COVID19 , also created a dilemma for lecturers in considering the sustainable use of E-learning in the future. This dilemma is related to the actualization of the role of accounting lecturers as agents of forming and strengthening the moral character of prospective accountants to minimize the practice of accounting fraud in the future.

The following are the details of the hypotheses generated from the research model related to $\mathrm{AD}, \mathrm{E}-$ Learning Dilemma, Sanctions on AD Practice and ELearning Preference:

Hypothesis 1: The seriousness of AD problems has a direct effect on the imposition of sanctions for $\mathrm{AD}$ actions by Accounting Lecturers;

Hypothesis 2: The seriousness of AD problems has an indirect effect on the Accounting Lecturer's E-learning Dilemma;

Hypothesis 3: The seriousness of AD problems has an indirect effect on the E-learning Dilemma of Accounting Lecturers through the imposition of sanctions for AD actions;

Hypothesis 4: The imposition of sanctions for $\mathrm{AD}$ actions has a direct effect on the Accounting Lecturer's E-learning Dilemma;

Hypothesis 5: The seriousness of AD problems has a direct effect on the Preference for the Use of Elearning by Accounting Lecturers;

Hypothesis 6: The seriousness of AD problems has an indirect effect on the Preference for the Use of Elearning through the E-learning Dilemma experienced by Accounting Lecturers;

Hypothesis 7: The imposition of sanctions has a direct effect on the Preference for the Use of E-learning by Accounting Lecturers;

Hypothesis 8: The imposition of sanctions has a direct effect on the E-learning Dilemma of Accounting Lecturers;

Hypothesis 9: The imposition of sanctions has a direct effect on the Preference for the Use of E-learning through the E-learning Dilemma experienced by Accounting Lecturers;
Hypothesis 10: The E-learning Dilemma has a direct effect on the Preference for the Use of E-learning by Accounting Lecturers.

\section{CONCLUSION}

The research problem focuses on the dilemma of E-learning by accounting lecturers and their impact on preferences for sustainable use of E-learning based on the Unified Theory of Acceptance and Use of Technology (UTAUT) by [4]. Another point of view that constructs the E-learning dilemma for accounting lecturers is also based on relevant empirical studies, e.g., [15], [14], [16], [17]. They highlighted that lecturers' understanding of the seriousness of $\mathrm{AD}$ problems and the imposition of sanctions for $\mathrm{AD}$ actions has a direct and indirect effect on the dilemma of adopting E-learning and preferences for sustainable use of E-learning.

The proposed study also underlines epistemology and ontology of the research framework on the influence of academic dishonesty, the E-Learning Dilemma, and its Impact on the Sustainability of the Use of E-Learning for Accounting Lecturers to strengthen the use of information systems in educational institutions. Thus, the results of this study based on the UTAUT perspective will provide an update on the whole and sustainable use of E-learning models by taking into account students' character/moral formation factors.

\section{REFERENCES}

[1] Sarabadani, J., Jafarzadeh, H., \& ShamiZanjani, M. Towards Understanding the Determinants of Employees' E-Learning Adoption in Workplace: A Unified Theory of Acceptance and Use of Technology (UTAUT) View. International Journal of Enterprise Information Systems (IJEIS), 13(1), 2017. pp. 38-49.

[2] Lee, Y. H., Hsieh, Y. C., \& Chen, Y. H., An investigation of employees' use of e-learning systems: applying the technology acceptance model. Behaviour \& Information Technology, 32(2), 2013, pp 173-189.

[3] Wang, M., Vogel, D., \& Ran, W. Creating a performance-oriented e-learning environment: a design science approach. Information \& Management, 48(7), 2011. pp. 260-269. http://dx.doi.org/10.1016/j.im.2011.06.003. 
[4] Venkatesh, V., Thong, J. Y., Chan, F. K., Hu, P. J. H., \& Brown, S. A. Extending the two-stage information systems continuance model: Incorporating UTAUT predictors and the role of context. Information Systems Journal, 21(6), 2011. pp. 527-555.

[5] Yoo, S. J., Han, S. H., \& Huang, W. The roles of intrinsic motivators and extrinsic motivators in promoting e-learning in the workplace: A case from South Korea. Computers in Human Behavior, 28(3), 2012. pp. 942-950.

[6] Cheng, B., Wang, M., Mørch, A. I., Chen, N. S., $\&$ Spector, J. M. Research on e-learning in the workplace 2000-2012: a bibliometric analysis of the literature. Educational research review, 11, 2014. pp. 56-72.

[7] Jones, P., Skinner, H., Sloan, D., Porter, E., Robins, K., \& McCourt, K. Using e-learning to support international students' dissertation preparation. Education+ Training. 2014.

[8] Rahimi, M. R., Ren, J., Liu, C. H., Vasilakos, A. V., \& Venkatasubramanian, N. Mobile cloud computing: A survey, state of art and future directions. Mobile Networks and Applications, 19(2), 2014. Pp. 133-143.

[9] Yoo, S. J., Huang, W. H. D., \& Kwon, S. Gender still matters: Employees' acceptance levels towards e-learning in the workplaces of South Korea. Knowledge Management \& E-Learning: An International Journal, 7(2), 2015. pp. 334347.

[10] Bobbitt, M. L. and Dabholkar, P. A. "Integrating Attitudinal Theories to Understand and Predict Use of Technology-Based Self-Service," International Journal of Service Industry Management, 12 (5), 2011. pp. 43-70.

[11] Kim, S., Haley, E., \& Koo, G. Y. Comparison of the paths from consumer involvement types to ad responses between corporate advertising and product advertising. Journal of Advertising, 38(3), 2009, pp. 67-80.

[12] Ajzen, I. From intentions to actions: A theory of planned behavior. In J. Kuhl \& J. Beckmann (Eds.), Action control from cognition to behavior (pp. 11-39). New York: Springer., 1985.

[13] Ajzen, I., \& Madden, T. J. Prediction of goaldirected behavior: attitudes, intentions, and perceived behavioral control. Journal of Experimental Social Psychology, 22, 1986, pp. 453-474.
[14] Aldosemani, T., Shepherd, C. E., \& Bolliger, D. U. Perceptions of Instructors Teaching in Saudi Blended Learning Environments. TechTrends, 63(3), 2019, pp. 341-352.

[15] Stahl, B. C. E-teaching-the economic threat to the ethical legitimacy of education?. Journal of Information Systems Education, 15(2), 2020, pp. 6.

[16] Peled, Y., Barczyk, C. C., \& Sarid, M. Institutional policies and faculty perceptions of student academic dishonesty. Educational Practice and Theory, 34(2), 2012, pp. 61-79.

[17] Peled, Y., Eshet, Y., Barczyk, C., \& Grinautski, K. Predictors of Academic Dishonesty among undergraduate students in online and face-to-face courses. Computers \& Education, 131, 2019, pp. 49-59.

[18] Dwivedi, Y.K., Rana, N.P., Janssen, M., Lal, B., Williams, M.D., \& Clement, M. An empirical validation of a unified model of electronic government adoption (UMEGA). Government Information Quarterly, 2017, pp 1-20. doi:10.1016/j.giq.2017.03.001

[19] Sykes, T. A., Venkatesh, V., \& Gosain, S.m Model of acceptance with peer support: A social network perspective to understand employees' system use. MIS quarterly, 2009, pp 371-393. 